\title{
Subacute inflammatory demyelinating polyneuropathy
}

INSERM

\section{Source}

INSERM. (1999). Orphanet: an online rare disease and orphan drug data base. Subacute inflammatory demyelinating polyneuropathy. ORPHA:206594

Subacute inflammatory demyelinating polyneuropathy (SIDP) is a subacute progressive symmetric sensorial and/or motor disorder characterized by muscular weakness with impaired sensation, absent or diminished tendon reflexes and elevated cerebrospinal fluid (CSF) proteins. SIDP is an intermediate form between Guillain-Barré syndrome (GBS) and chronic inflammatory demyelinating polyneuropathy (CIDP; see these terms). 